\title{
Traditional versus modern settlement on torrential alluvial fans considering the danger of debris flows: a case study of the Upper Sava Valley (NW Slovenia)
}

https://doi.org/10.1515/geo-2019-0050

Received April 17, 2019; accepted August 7, 2019

\begin{abstract}
We analysed spatial development of traditional and modern settlements on active alluvial fans in the Upper Sava Valley (NW Slovenia), by using old cadastral data from the beginning of the 19th century, time series of aerial photographs from the middle of the 20th century and recent building cadastre. The valley is surrounded by the mountainous Julian Alps in the south and the Karavanke Mountains in the north where there is a lack of space for settlements due to steep slopes that are increasing the danger of slope processes, torrential processes and floods.

By using a very high-resolution 1m LiDAR digital elevation model, we defined the morphometry of alluvial fans and the characteristics of the drainage system of contributing tributaries. We classified the areas according to the threat posed by the modelled torrents and debris flows. We analysed the resilience of settlement in different periods from this perspective and evaluated the integration of natural processes effects in modern spatial planning projects. We found that geomorphic processes threaten a relatively large proportion of some new and old settlements on alluvial fans and that safe planning of areas of settlement has been successful neither in the past nor in recent decades.
\end{abstract}

Keywords: resilience, natural hazards, torrential floods, debris flows, settlements, alluvial fans, Julian Alps, Karavanke Mountains

\footnotetext{
`Corresponding Author: Mateja Breg Valjavec: Anton Melik Geographical Institute ZRC SAZU Ljubljana, Slovenia, E-mail: mateja.breg@zrc-sazu.si

Blaž Komac: Research Centre of the Slovenian Academy of Sciences and Arts, Anton Melik Geographical Institute, Ljubljana, Slovenia
}

\section{Introduction}

\subsection{Risk of debris flows in the Alps}

Settlement of alluvial fans is a traditional form of settlement in Alpine countries [1]. Alluvial fans are favourable for settlement because of their distance from major rivers and alluvial floods, higher insolation and the possibility of agriculture. Due to lack of space, steep slopes, the danger of slope processes, and floods, traditional settlement in the Alps were built mainly on torrential alluvial fans. The buildings avoided only on the most hazardous (active) alluvial fans. Since the positioning of traditional settlements is based on social memory on natural disasters [2], the oldest buildings prevail in areas with the low threat of natural disasters [3]. Building on alluvial fans is not just a matter of withdrawing from flash floods, but also debris flows, which, despite their rarity, are dangerous due to their size, high speed and the deposition of large quantities of debris $[4,5]$. Modern spatial planning at the local level is usually supported with expert studies on torrential processes on alluvial fans and it is only rarely extended with participatory planning methods [6] that consider local stakeholders and inhabitants. The role of stakeholder participation in spatial planning has gradually increased but, participation remains at a rather unsatisfactory level, mainly because of its proforma character and practitioners' insufficient knowledge on how to implement it [7].

In the Alpine environment, local knowledge is of high importance because of the high variability of debris-flow activity [8]. In the Alps, torrential flows are commonly triggered by intense rainstorms of short duration and high intensities or long-lasting precipitation, often related to fast snowmelt [9]. Recent extreme debris flow and hyperconcentrated flow events in the Alps have shown the enormous destructive impact power on buildings, bridges and roads on one hand, and the limits of "classical" torrent control measures on the other $[10,11]$. Torrential processes 
constitute a widespread hazard and they repeatedly cause severe damage and destruction to settlement areas, transportation corridors, and infrastructure or even lead to loss of life, especially on alluvial fans and debris cones [12]. Hazard assessment in these areas depends on proper identification of the dominant sedimentary processes on the fans [13]. Most of the studies focus on debris-flow event chronology at national [11], regional [8] and local levels and discuss the influential factors. Catchment morphology, geology, climatic change and land-sliding within the catchments and land use were also recognized as important controls [13]. Despite the known importance of land use, some authors $[7,8]$ joined the aspect of torrential hazard events to social process, specifically with the settlement and spatial planning.

As we face lack of sedimentological and archival data, thus the frequency and intensity of natural processes on the alluvial fans are generally unknown. Consequently, there is no memory of them, either among the people or in available documents, that could be applied in spatial planning documents [14-16]. Settlements - completely legally - extend to hazardous areas, resulting in future problems [17].

Old maps and other cartographical data (e.g. Franciscan Land Cadastre - first cadastral maps for Slovenian territory from (1818-1828)) are often used to provide historical records on the development of settlements and processes $[18,19]$. Existing land cover maps, aerial imagery can be used for the analysis and evaluation of Alpine alluvial fans [20] or other land degradation processes in mountain areas [21]. The reconstruction of the frequency of past events from historical archives is particularly fruitful where human activities are present providing documentation on past events and related damage [22-24]. Using these data also the magnitude of past hydrogeomorphic events can be estimated, thus permitting to establish magnitude-frequency relations $[20,25,26]$. In the paper, we sought an answer on how much natural processes' effects were taken into account in modern spatial planning of the settlements on alluvial fans in the Sava Valley, NW Slovenia [3]. The answer is a complex one, reflecting the complex relationship between the interests and capacities of individuals, the municipalities (managing spatial planning), the administrative units (issuing building permits) and investors, who encourage unsustainable interventions in hazard areas [27]. The outline of the natural hazards of this area is followed by a review of known flood events and, in the central part of the paper, we present a quantitative analysis of the historical development of settlement on active alluvial fans, based on an analysis of his- torical aerial images from 1954/1966 to 2011 (Figure 1), providing the relations to hazardous areas.

\subsection{Description of the study region}

The paper deals with the Upper Sava Valley, located between the Julian Alps (Slovenia) in the south and the Karavanke Mountains in the north. The Julian Alps are marked by limestone and dolomite rocks that are recognized by several hundred-metre high dolomite steep slopes and walls in the Vrata Valley, steep slopes in the Velika Pišnica and Tamar valleys, characterized by erosion $[16,28]$. These areas deliver massive amounts of torrential material that build alluvial fans and cause flash floods in the valleys [29]. Sava Dolinka River, the main watercourse in the area, gathers water from both mountain ranges. Recently, the vulnerability of settlement to debris flows is determined by field measurements, as well as by various geoinformatics methods. Based on measurements of the quantity of debris for the Javornik barrier and utilizing mathematical modelling of the transfer capacity, $301,770 \mathrm{~m}^{3}$ of the material is released into the river basin of the Sava Dolinka River annually, corresponding to $1105 \mathrm{~m}^{3}$ of material per $\mathrm{km}^{2} /$ year. $52 \%$ of the material arrives at the hydrological cross-section $\left(158.216 \mathrm{~m}^{3}\right.$ of material or $580 \mathrm{~m}^{3} / \mathrm{km}^{2} /$ year); the rest remains in an unstable position on the slopes higher up in the riverbed. Besides, about $68,366 \mathrm{~m}^{3}$ or $126,000 \mathrm{t}$ of suspended load [30] is transported per year. Data for recent decades show a decrease in water discharges [31] and the sediment transport, consequently lowering the erosion rates, being a result of the regulation of torrents through the construction of barriers decades ago and afforestation of the area [Jesenovec 1995]. The barriers are often overgrown, destroyed or buried today [28, 32-34].

The study included six settlements on alluvial fans (Figure 1) that are exposed to torrential floods and debris flows. Two of them were developed by past debris flows from the southern Julian Alps and are today partially built up by two touristic settlements (Kranjska Gora and Mojstrana), and four fans (Trebiža, Krotnjek/Suhelj, Belca, Bela fans) that were developed by debris flows from Karavanke Mountains from the north. On these fans, Rateče, Podkoren and Belca villages that are potentially exposed to debris flows from Karavanke Mountains. Koroška Bela has recently developed (as a settlement exists from 2015) in a suburban part of the Jesenice City, the main and the biggest urban settlement in the Upper Sava Valley, known by its steel industry. 


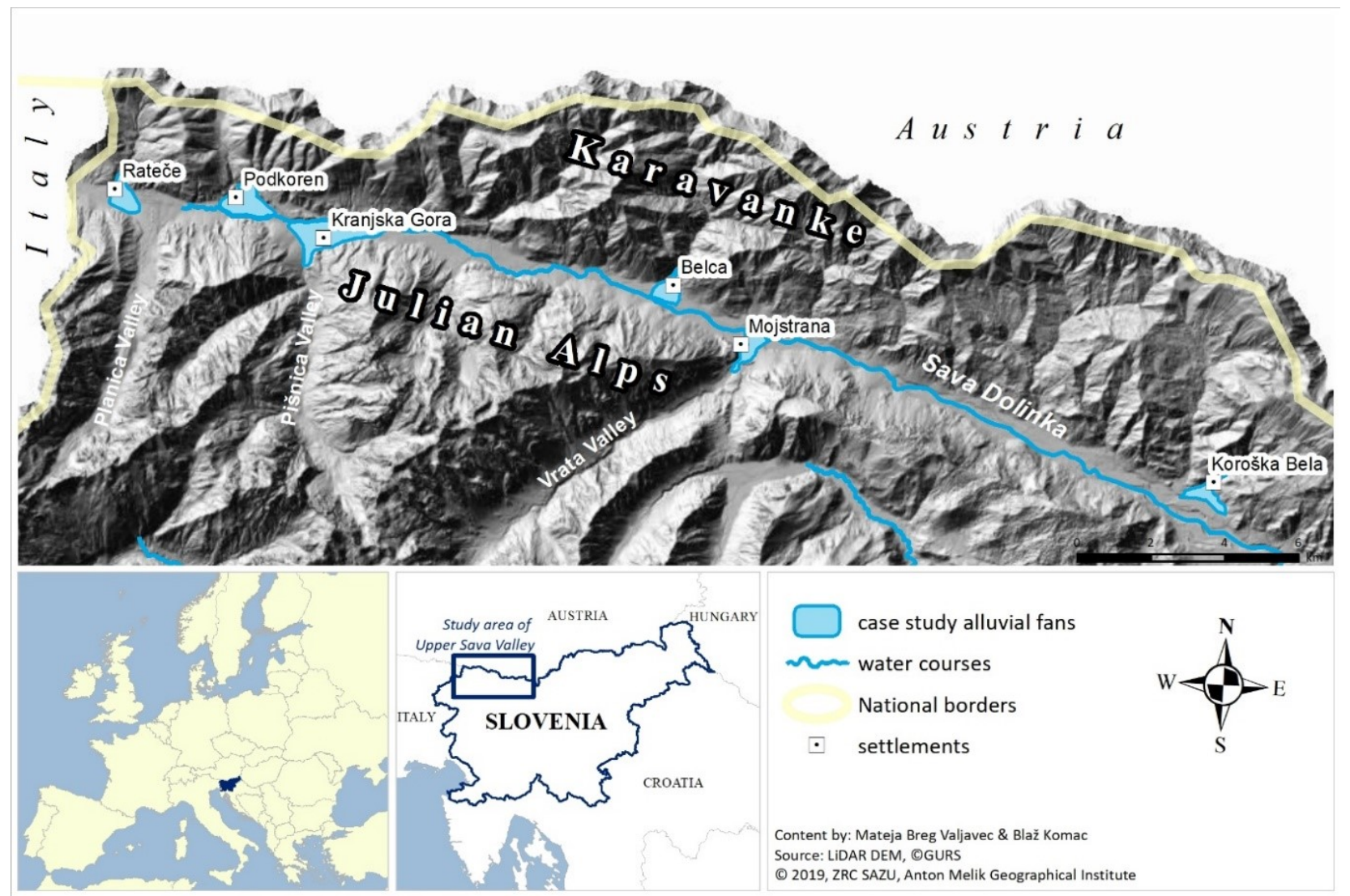

Figure 1: Upper Sava Valley as a case study area with many torrential alluvial fans. Six alluvial fans (4 from Karavanke Mountains and 2 from the Julian Alps) were selected to evaluate hazards to the traditional and modern settlement of six villages, namely: Rateče, Podkoren, Kranjska Gora, Belca, Mojstrana, Koroška Bela.

\section{Data and methods}

\subsection{Geomorphic mapping}

According to Marchi et al. [20], three steps can be highlighted in the hazard assessment on alpine alluvial fans: - recognition of the type of sediment transport processes; - reconstruction of the frequency and magnitude of hazardous events;

- runout analysis and mapping of hazardous areas.

The first part of this research presents an analysis of morphometric relationships between alluvial fans and their drainage basins. First of all, we delineated the area of alluvial fans based on the geomorphological analysis. The boundary of an alluvial fan, as well as its geomorphological characteristics, were determined by GIS and expert analysis of the LIDAR digital elevation model (1 m resolution). Laser scanning of Slovenia took place between 2011 and 2015, while the Upper Sava Valley was scanned in 2014, 5 points $/ \mathrm{m}^{2}$ (2 points $/ \mathrm{m}^{2}$ in the high Julian Alps) [35]. We used the classified cloud of points for the Upper Sava
Valley area and assessed the usefulness of the data for geomorphological determination of alluvial fans. The data reveal relief forms, including those that are covered by vegetation, such as. paleo-riverbeds. Catchments of torrents were determined by hydrological analysis of the digital elevation model in the ArcGIS program, using the Spatial Analyst module. We calculated the morphometric properties of the alluvial fans that are significant for the formation of torrents and debris flows [4] and categorized them by their geomorphic hazard potential.

Based on available data [4] we analysed the debris flow risk in three settlements on alluvial fans (Rateče, Podkoren, Koroška Bela) and assessed the usefulness of various types of spatial data (topographic, cartographic, painting etc.), to analyse the complex development of flood hazard [36] over time.

\subsection{Mapping of settlement dynamics}

We determined the changes in settlements by using geohistorical approach and studying time series of different 
historical data that enable the recognition of natural and social changes in the landscape (e.g. the growth of the settlement etc.) [37-39]. We used historical cartographic and imagery sources, such as the Franciscean Land Cadastre (1818-1828) and its updated version, the so-called "reambulated" cadastre (1869-1887), to determine the extent of traditional settlement on alluvial fans by considering that they can be affected by torrential floods. The pattern of traditional settlement was determined based on buildings marked on the Franciscean Cadastre, which in this area dated in the year 1826. Based on the oldest existing aerial recordings (from 1954 and 1966, depending on the case of alluvial fan and available images) and recent aerial recordings (2011), we studied changes in the settlements (number and extent of buildings) that occurred after the World War II. The images are available in the Historical Aerial Archives of Slovenia [39]. The historical and spatial dynamics of settlement growth were determined by comparing the situation in the Franciscan Cadastre with current situation and, in the majority of cases (except for Koroška Bela, where no data exist for the same period), the intermediate situation from the middle of the 20th century (for the years 1954 (Rateče, Podkoren, Belca, Kranjska Gora), and 1966 (Mojstrana)). Aerial imagery was automatically georeferenced and visually interpreted. This procedure is not a major technical problem, especially for the images recorded since World War II and is obtained with relatively simple geo-information analytical tools. The results were evaluated the perspective of the hazard of settlements in individual periods.

\section{Results}

The results of alluvial fans geomorphology and settlement dynamic for all six studied alluvial fans are presented briefly (Figure 2, Table 1) from the perspective of changes in buildings and are further discussed concerning debris flow danger and risk management is section Discussion.

\subsection{Alluvial fans of Karavanke Mountains}

The alluvial fan of Trebiža (Figure 2A) covers $0.51 \mathrm{~km}^{2}$ while its water-catchment area is almost ten times larger, covering $4.79 \mathrm{~km}^{2}$. Its catchment area reaches high elevations (1200 $\mathrm{m}$ a.s.l.) but the relative altitude difference between the catchment highest peak and lowest area in the valley of $680 \mathrm{~m}$ is relatively small for the Upper Sava Valley. The discharge with a 100-year return period is moder- ate $\left(40 \mathrm{~m}^{3} / \mathrm{s}\right)$ as well. The average gradient of the catchment area is relatively low with $22.6^{\circ}$, while the highest slope gradient being $46^{\circ}$. The catchment consists predominantly of unconsolidated breccias, carbonaceous clay, silt and dark grey quartz sandstone and conglomerate. The predominant land use in the catchment area is a forest, which is favourable in terms of water retention and prevention of erosion. The older part of Rateče Settlement is built in the upper half of the fan since the wet meadows in the lower part are often flooded. By 1826, 60 buildings had been built on the safer eastern part of the alluvial fan, with a total area of $10,871 \mathrm{~m}^{2}$. The number of buildings has to date increased by 3.6 times, to 220 , while the building area has increased to $29,644 \mathrm{~m}^{2}$. The greatest increase was in the period from 1826 to 1954 , mainly due to condensation of buildings in the central part of the settlement and its spread to the western edge.

Downwards in the Upper Sava Valley, the Podkoren alluvial fan has been formed (Figure 2B) by two equally long $(3.2 \mathrm{~km})$ left tributaries of the Sava River, flowing from Karavanke Mountains: Krotnjek Torrent in the west and Suhelj Torrent in the east. Forest is dominant today, while in past (1880-1890) an erosion hotspot formed at an altitude of $1300-1550 \mathrm{~m}$ a.s.l., from which 700,000 to $800,000 \mathrm{~m}^{3}$ of sandy-clay material was re-transported by the waters. The alluvial fan area $\left(0.509 \mathrm{~km}^{2}\right)$ is nine times smaller than the area of its catchment $\left(4.67 \mathrm{~km}^{2}\right)$. The relative attitude difference in the catchment area is $770 \mathrm{~m}$. The average slope gradient in the catchment is $28^{\circ}$, while the highest slope gradient is $59^{\circ}$. The catchment consists predominantly of carbonaceous clay, silt and dark grey quartz sandstone and conglomerate. In terms of the settlement growth, Podkoren Settlement has a similar development as Rateče Settlement. The number of buildings on the alluvial fan has increased from 78 (in the year 1826) to 283 (in the year 2016) in nearly 200 years.

Although Belca alluvial fan measures $381,316 \mathrm{~m}^{2}$ and is the smallest among studied alluvial fans it has a large catchment area $\left(17.6 \mathrm{~km}^{2}\right)$. Belca fan was traditionally settled before 1826 by 15 buildings (Figure $2 \mathrm{C}$, Table 1), while the construction increased in the second half of the $20^{\text {th }}$ century and reached a total of 52 buildings. This is the less densely populated alluvial torrential fan.

Bela alluvial fan is partially built up by the settlement of Koroška Bela. It measures $0.46 \mathrm{~km}^{2}$. Its fairly steep catchment area $\left(28^{\circ}\right.$; the highest slope gradient being $\left.+62^{\circ}\right)$ is $6.0 \mathrm{~km}^{2}$. The relative height difference is $1500 \mathrm{~m}$. The watercourse has a moderate slope gradient of $6.8^{\circ}$. Due to the proximity of Jesenice City, the alluvial fan is among the most densely populated in the Upper Sava Val- 
ley (Figure 2D). From the initial 31 buildings (1826), the number of buildings has so far increased to 355 .

\subsection{Alluvial fans of Julian Alps}

The Pišnica alluvial fan in Kranjska Gora (Figure 2E) is the largest of the studied alluvial fans $\left(1.5 \mathrm{~km}^{2}\right)$ and is most densely populated. Its catchment covers $36 \mathrm{~km}^{2}$, with a relative height difference of $1,900 \mathrm{~m}$. The average gradient of the catchment area is $36.0^{\circ}$, while the highest gradient being $80.0^{\circ}$. Recently, there are 684 buildings in Kranjska Gora built and on the Pišnica alluvial fan, covering $138,703 \mathrm{~m}^{2}$ of the area or $9.1 \%$ of the surface of the alluvial fan. It is one of the most urbanized alluvial fans in the Upper Sava Valley, where most of the buildings are used in tourist purposes since Kranjska Gora is a well-known ski resort.

The Bistrica alluvial fan in Mojstrana Settlement (Figure $2 \mathrm{~F}$ ) has formed an elongated alluvial fan, measuring $0.58 \mathrm{~km}^{2}$. Bistrica Torrent is the longest $(12.6 \mathrm{~km})$ of the described torrents and has the largest catchment area $\left(44.8 \mathrm{~km}^{2}\right)$. The gradient of the watercourse is slightly greater than that of the Pišnica Torrent $\left(2.3^{\circ}\right)$. The relative height difference being 2,200 $\mathrm{m}$ and the average slope gradient is $35.0^{\circ}$ while the highest slope gradient being $79.0^{\circ}$. In Mojstrana Settlement, the largest concentration of old buildings appears in the lower part of the alluvial fan. In 1826 , there were 40 buildings, and their number had increased to 342 by 2016 .

\section{Discussion}

\subsection{Risk of debris flows to traditional and modern settlement: Karavanke Mountains versus the Julian Alps}

According to acquired results and available existing data on debris flows [4], we defined that the alluvial fans of the Julian Alps are about four times larger than those of the Karavanke Mountains and they have a higher slope gradient and steeper river beds $\left(26^{\circ}: 34^{\circ}\right)$. The Alpine watercourses are twice the length of those in the Karavanke Mountains (the latter on average $4.6 \mathrm{~km}$ long and in the Julian Alps $8.6 \mathrm{~km}$ ) and have almost three times the 100-year flow rate $\left(53: 135 \mathrm{~m}^{3} / \mathrm{s}\right)$. Six times more material is released on their catchment areas (on average $44,50 \mathrm{~m}^{3}$ ) than in the Karavanke $\left(6,88 \mathrm{~m}^{3}\right)$. The Karavanke alluvial fans are steeper $\left(15^{\circ}: 5^{\circ}\right)$ due to the effect of lithology and tectonics and have a higher mean Melton number (0.40), which is just below the boundary of debris flows in the Julian Alps (0.27) [4]. Together with much steeper slope gradient, they indicate a higher frequency of intensive geomorphic processes and debris flows $\left(4.8^{\circ}: 1.5^{\circ}\right)$. All this proves that alluvial fans of Karavanke Mountains pose a greater risk to existing settlements and human activities than those in the Julian Alps.

Along with the high awareness on the risk of torrential processes, in the 20th century, the Upper Sava Valley experienced rapid development, reflected in the increasing number of new buildings on the all six studied alluvial fans (Table 1, Figure 3). It is noteworthy that the Karavanke alluvial fans, which pose a greater risk than those in the Julian Alps [4], were populated later but there are fewer buildings on them than on the Julian Alps alluvial fans. The dynamics in several buildings followed the population dynamics (Figure 4). In 1869 Rateče and Kranjska Gora were the most populated and also important villages among studied fans. In the 20th century, the number of inhabitants on both fans of Julian Alps increased about $100 \%$ while the population of Karavanke fans remained almost unchanged or even decreased (Figure 4). Koroška Bela Settlement that is endangered by the torrential process of Bela Torrent was not included in population analysis as data are not available for period 1869-2015. Namely, Koroška Bela Settlement was established in 2015 as a part of Jesenice City, therefore data are available from 2015 on when 2,127 inhabitants were recorded (Statistical Survey of the Republic of Slovenia).

In continuation, we present some main challenges and issues of torrential alluvial fans. The results give input to a discussion on historic changes of the settlements and its relation to risk management. For three of the Karavanke fans, the models on the danger of debris flows were made by Mikoš \& Jošt [4], thus we included them in discussion and presented on the map (Figure 5).

Almost half of the Trebiža alluvial fan (44.7\%) and more than half of the buildings $(60.5 \%$ and 133 respectively, out of 220) are nowadays at risk (Figure 5). Among old buildings, 44 (73.3\% of all at risk and one-fifth of all buildings in the settlement) are exposed to debris flows, 58 out of 96 buildings built between 1826-1954 (60.4\% of all at risk and a quarter of all buildings in the settlement), while 31 new buildings are at risk among new buildings ( $48.4 \%$ of all at risk and $14.1 \%$ of all buildings in the settlement). The older, eastern part of the Rateče Settlement [40] is safer from floods than the western part, which lies on the alluvial fan of the Trebiža Torrent on the southern exposition of Karavanke Mountains (Figure 5). Recently, 


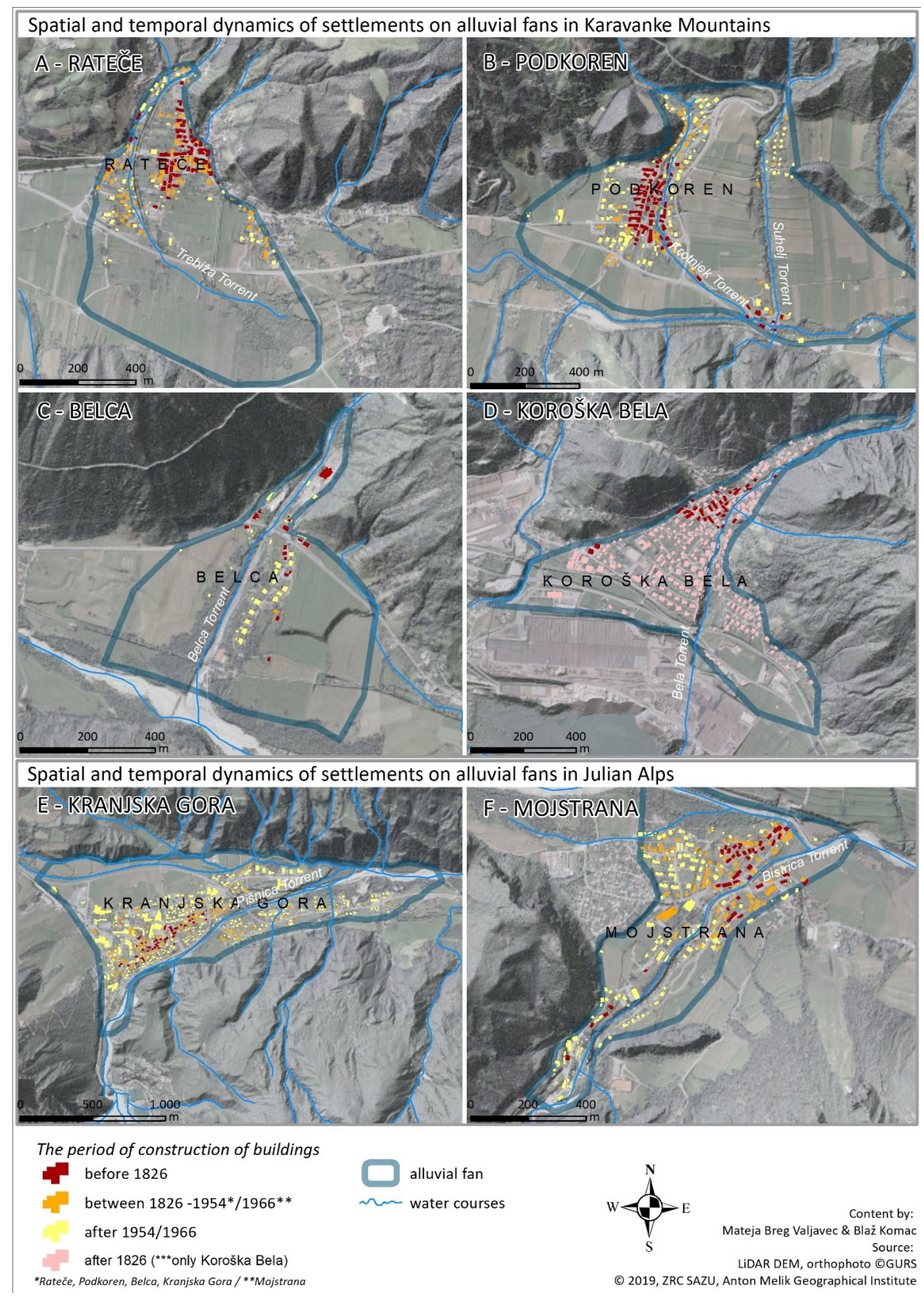

Figure 2: Changes in the settlements on alluvial fans in the Upper Sava Valley. Images A - D represent alluvial fans of Karavanke Mountains and images E-F represent alluvial fans of Julian Alps.

frequent torrential floods with abundant sediment transportation occurred. The oldest studied alluvial fan sediments were deposited by three debris flows, while recently fluvial sedimentation is the prevailing natural process [32]. Although torrential floods are transporting and depositing large quantities of sediment and cause damage to fields and buildings, the debris flows are not likely to occur on the Trebiža alluvial fan [4].

Podkoren Settlement experienced an expansion of building after 1954 when the number of buildings more than doubled (Figure 2B). The Suhelj Torrent threatens (Figure 5) a tenth of the buildings (31 of 283). Although the area at risk was already built during the earliest age ( 7 buildings of the then 78) and the same number of buildings originated in the period before 1954, when 60 buildings were built, there were 145 buildings in the newest period, of which 14 are at risk. After World War II, wooden barriers were built, today being buried and damaged [32]. The catchment area of the Krotnjek Torrent $\left(3.7 \mathrm{~km}^{2}\right)$ is larger than the Suhelj Torrent $\left(1.9 \mathrm{~km}^{2}\right)$. Krotnjek Torrent 
Table 1: In the table, we present six case study fans considering their surface area and size and built-up area. * Settlements for wich aerial

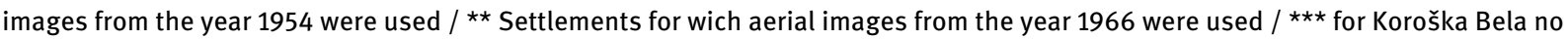
archive images were available.

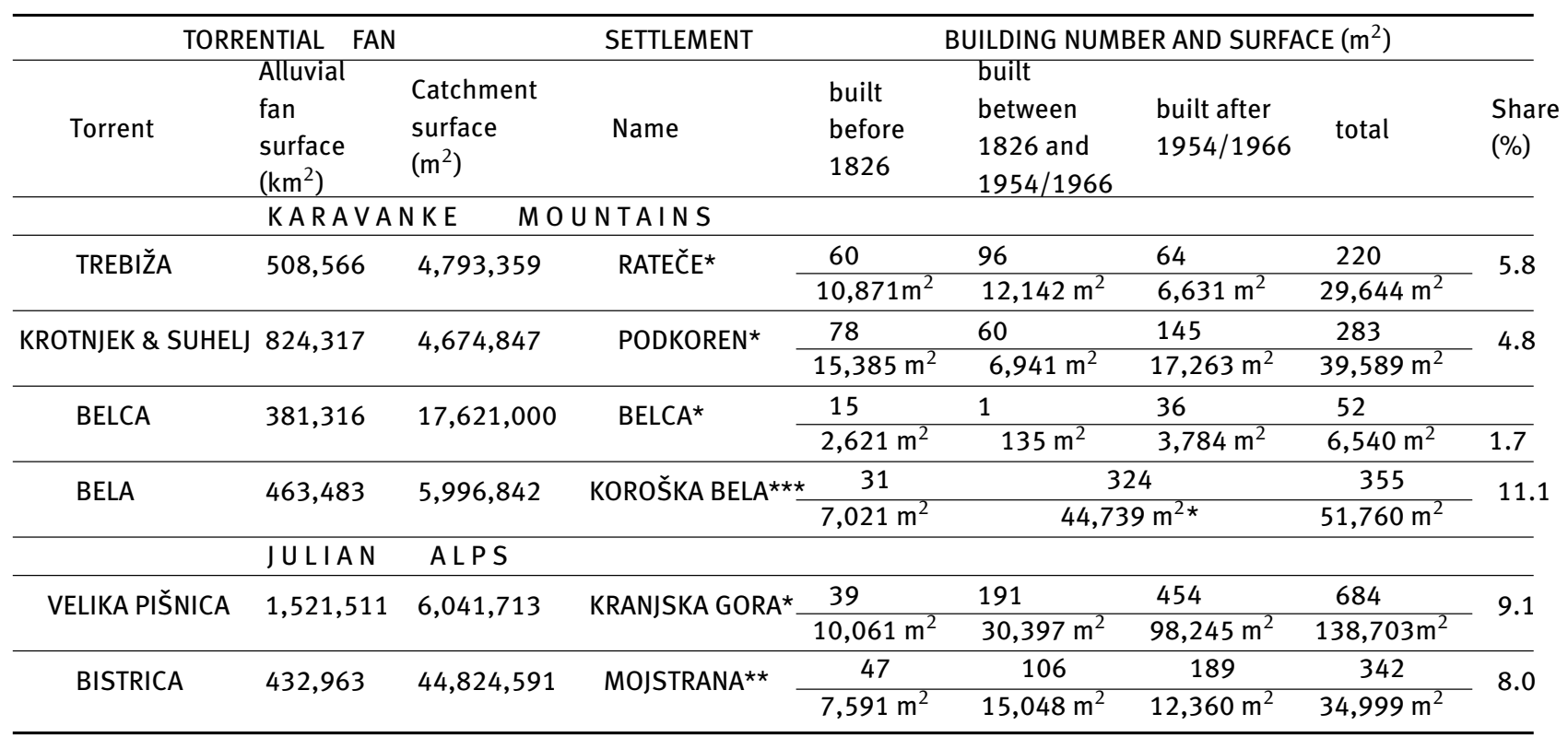

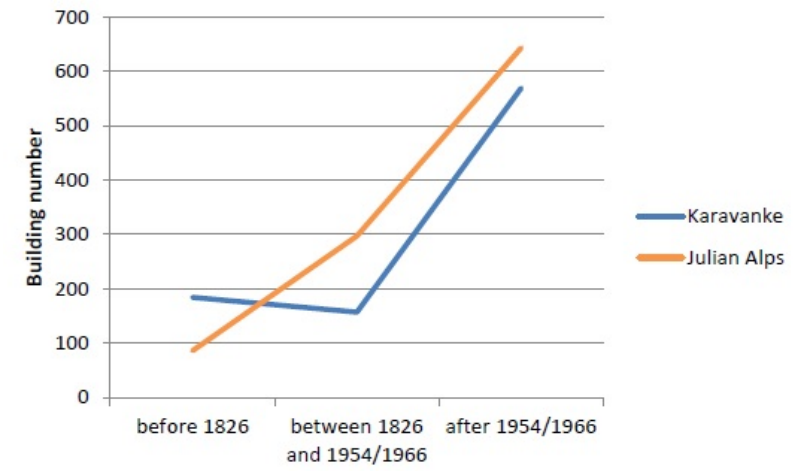

Figure 3: Karavanke alluvial fans (blue line) pose a greater risk than those in the Julian Alps (orange line) thus, they were populated later and fewer buildings were built on them than on the Julian Alps alluvial fans.

also has a higher flow rate $\left(36: 23 \mathrm{~m}^{3} / \mathrm{s}\right)$ with a 100 -year return period. This torrent is as well steeper $\left(9.6^{\circ}: 5.5^{\circ}\right)$ and it has formed twice as steep alluvial fans $\left(6.8^{\circ}: 2.9^{\circ}\right)$ as Suhelj Torrent. On the other hand, Krotnjek Torrent is less threatened by debris flows [4]. Suhelj Torrent is among most exposed alluvial fans in the area due to the high gradient. Nevertheless, a hamlet with several buildings was built near the torrent being evident even in the oldest studied maps. Although there are no remains on the surface that would prove past dangerous processes, the past processes can be identified in sediments [32].

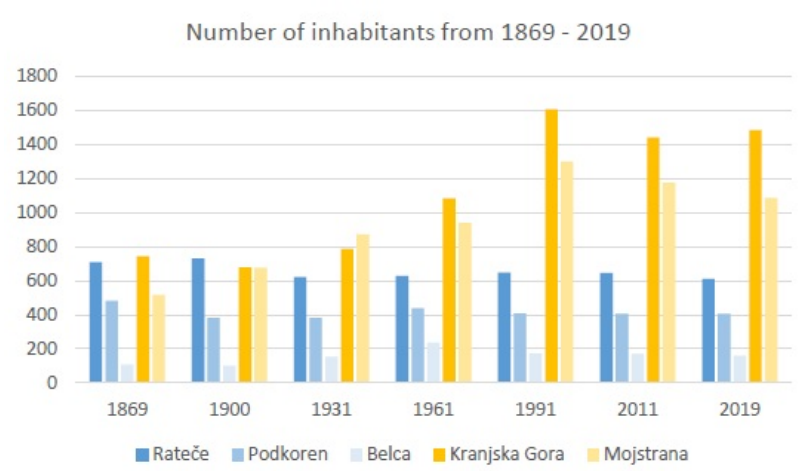

Figure 4: Karavanke alluvial fans (blue coloured column bars) were populated later than the Julian Alps alluvial fans (orange coloured column bars).

In addition to the high slope gradient of the alluvial fan of Bela Torrent $\left(5.2^{\circ}\right)$, the most forested area is characterized by a moderately high specific release of material $\left(800 \mathrm{~m}^{3} / \mathrm{km}^{2} /\right.$ year) and high debris flow hazard [4, 32]. Recently, debris flows threaten almost one-quarter of the Koroška Bela settlement on the alluvial fan $\left(0.11 \mathrm{~km}^{2}\right.$ out of $0.46 \mathrm{~km}^{2}$ ), while more than a third of the buildings are at risk (121 out of 355). Some events from the past are also recorded. On $13^{\text {th }}$ of November in 1789, after heavy rains, debris flows covered and damaged 47 houses and destroyed several mills. Since the Bela Torrent was also blocked, there was flooding in the village until new channels were dug. Besides, a landslide on Potoška Planina 


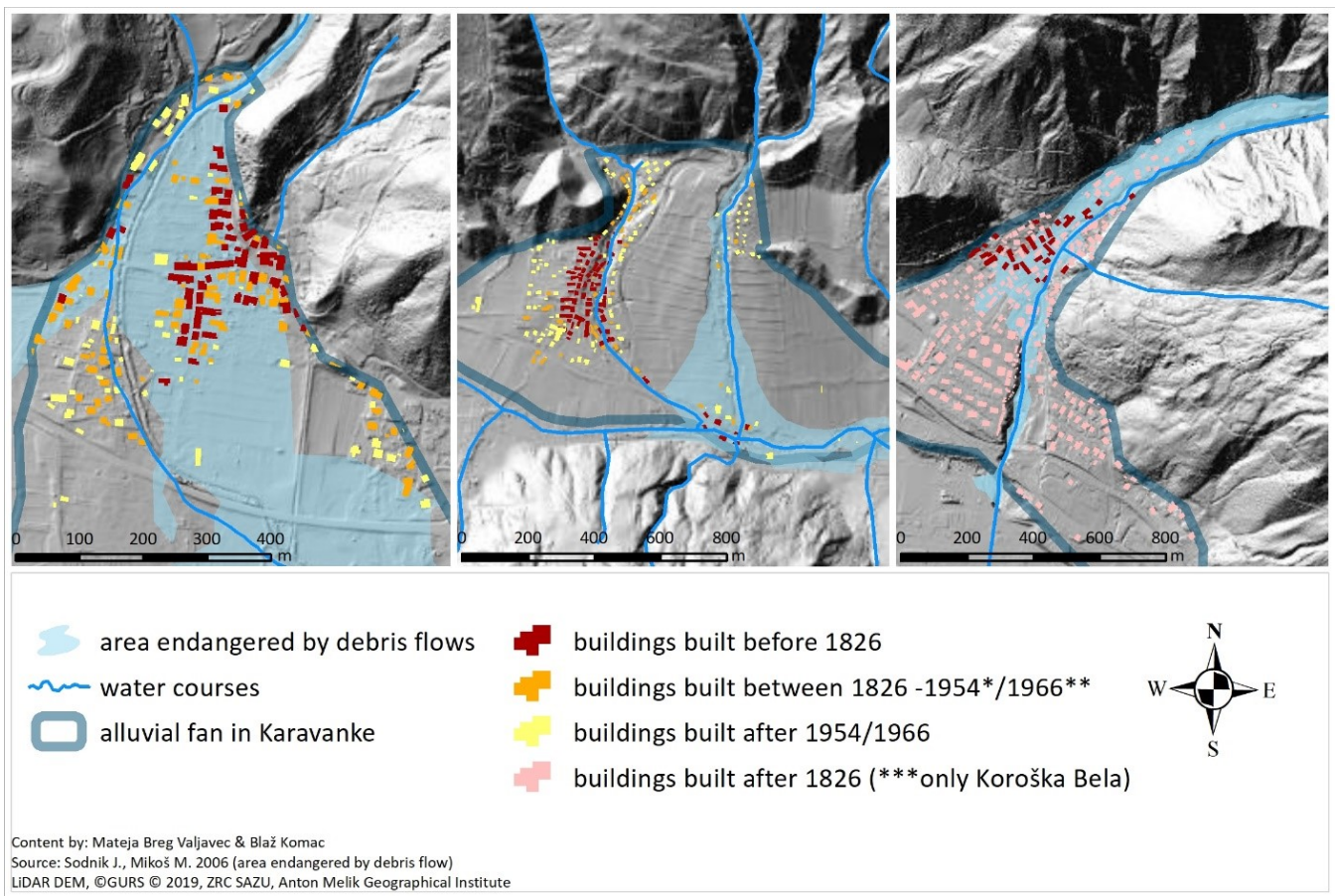

Figure 5: The Karavanke Mountains alluvial fans pose a great risk to settlements, transport and other human activities thus, some predictions were made by modelling danger of debris flows [4]. The figure presents the part of settlements Rateče (left image), Podkoren (middle image) and Koroška Bela (right image) that are endangered by debris flows.

Plateau and a more dangerous active landslide under the Urbas Spring pose threat to Koroška Bela, where debris flow may affect approximately 2,200 inhabitants [41].

Although the Belca Torrent (Belca fan) (Figure 2C) is not particularly hazardous for the formation of debris flows [Jošt \& Mikoš 2006], it has a large catchment area $\left(17.6 \mathrm{~km}^{2}\right)$ with a very high gradient of the alluvial fan $\left(33^{\circ}\right)$ and dolomite erosion hotspots causing a fairly high specific release of sediments $\left(1040 \mathrm{~m}^{3} / \mathrm{km}^{2} /\right.$ year $)$. Similar as Velika Pišnica Torrent (Kranjska Gora), this watercourse has one of the highest annual releases of sediments $\left(18,300 \mathrm{~m}^{3}\right)$ [4], and the average flow rate with the 100-year return being $107 \mathrm{~m}^{3} / \mathrm{s}$. Despite the large relative height difference and large catchment area, the Belca Torrent has torrential character because of the low alluvial fan gradient $\left(3^{\circ}\right)$. The Belca Torrent created an $800 \mathrm{~m}$ long and 50$120 \mathrm{~m}$ wide alluvial fan, on which the national road was damaged twice (in 1945 and 1952), the railroad bridge was damaged (1952) and, on 11th of November in 1951, it caused a train to derail on the Jesenice-Rateče line. In 1966, the torrent destroyed the bridge and buried a sawmill [Jesenovec 1995], as the same occurred in 2018. It can be assumed that the low number of buildings (52) concerning other fans is a result of the high frequency of hazardous events in not so remote history.
Despite the high altitude difference, the high maximum discharge $\left(128 \mathrm{~m}^{3} / \mathrm{s}\right)$ and abundance of surface erosion (1800 $\mathrm{m}^{3} / \mathrm{km}^{2} /$ year) in the mostly dolomite hinterland of Pišnica Torrent catchment [Kunaver 1990], there is no possibility of debris flow formation. However, there are 30 major and minor erosion hotspots in the Pišnica Valley that were already regulated before 1900 . The protection of Kranjska Gora, which had been repeatedly struck by floods [42], was provided in 1894 with building a flood barrier and 50 erosion prevention activities. In the period between 1983 and 1992, 100,000 $\mathrm{m}^{3}$ of the material was disposed behind the Jasna barrier (above Kranjska Gora), corresponding to about $11,100 \mathrm{~m}^{3} /$ year or $66,600 \mathrm{~m}^{3} / \mathrm{km}^{2} /$ year. The same case is with Bistrica Torent fan and catchment. Due to its size, on the alluvial fan of Bistrica Torrent (Mojstrana Settlement) highest flow rates with a 100-year return period reach almost $200 \mathrm{~m}^{3} / \mathrm{s}$. Although data on the release of material in the hinterland is not available, the size of the catchment, the low gradient of the alluvial fan $\left(0.8^{\circ}\right)$ and accumulation of sediments above the settlement make the settlement safe [4]. In terms of shape, the alluvial fan is similar to Trebiža alluvial fan, but here the pattern of traditional settlement is completely different. 


\subsection{What did and what can spatial planers learn from traditional settlement?}

Did traditional settlement on alluvial torrential fans in the Upper Sava Valley consider the danger of debris flows? The traditional settlements in the Karavanke Mountains have taken into account the geomorphic hazard. In the past, the settlement avoided the most endangered areas. Our analysis of traditional settlements gives useful spatial guidelines to decision-makers, spatial planners and investors about safe areas.

Did modern settlement (second half of 20th century) on alluvial torrential fans in the Upper Sava Valley consider the danger of debris flows? Some events that continuously affect alluvial fans settlements in the Upper Sava Valley pose pieces of evidence contra this statement.

In 1885, the debris flow of the Trebiža Torrent buried almost 12 ha of fields and meadows. The last major floods were in August of 2003 when 274 mm rain fell in Rateče Settlement in three days, with a 130-year return period. During the same event, abundant material has been deposited on an inactive Planica alluvial fan with the Planica Nordic Centre. This alluvial fan joins the Trebiža alluvial fan [43]. The torrent transports an abundant amount of sediments, so a stone barrier was built to direct the waters and sediments away from the parking area and the ski jumping resort. The Planica Nordic Centre was last affected by floods on 2nd February 2019. A large transport of sediments can occur in the area, as evidenced by the occurrence of an $80,000 \mathrm{~m}^{3}$ debris flow on the western slopes of Mount Ciprnik (1745 m.a.s.l.) triggered on 18th of November 2000 [43].

At the 2003 event, the torrents in the Sava Valley flooded the alluvial fans while the nearby Valcanale/Kanalska Dolina Valley (in Italy) was affected as well. The discharge of the Sava Dolinka River reached a 50-year return period $\left(35.6 \mathrm{~m}^{3} / \mathrm{s}\right)$ in Kranjska Gora (Figure $2 \mathrm{E}$ ). On the basis of historical data dating back to the 16th century, it was estimated that such major events have a return period of 25 years in Valcanale [44-48]. Some of the listed events and many others recorded in last decades prove that modern spatial development of the settlements in the Upper Sava Valley in the post World War Ii period has ignored this aspect, thereby reducing the landscape's resilience to natural disasters. To increase the use of participatory processes in risk management and spatial planning of areas endangered by debris flows, it is important 1) to ensure participation in spatial planning processes to support sustainable spatial development, 2) to inform practitioners about participatory methods and techniques [6], and 3) to raise awareness about natural hazards in the area.

\section{Conclusion}

The goal of the paper was to give an answer on how much natural processes' effects were taken into account in modern spatial planning of the settlements on alluvial fans in the Sava Valley, NW Slovenia Recent situation is a reflection of the complex relationships between the interests and capacities of individuals, the municipalities (managing spatial planning), the administrative units (issuing building permits) and investors, who encourage unsustainable interventions in hazard areas. Despite the relative closeness, the Karavanke alluvial fans are more dangerous to settlements than alluvial fans from the Julian Alps. While the traditional settlement of fans (especially in Karavanke Mountains) was rather adapted to natural conditions, we found that modern spatial development of the settlements has ignored this aspect, reducing the landscape's resilience to natural disasters.

Despite of all, Upper Sava Valley is a good example of coexistence of local population with geomorphic torrential processes that influenced human activities and the spatial distribution of settlement in Alpine landscape. Although intense use of the mountain areas by grazing in pre-industrial times changed the landscape and the process even increased in the harsher climatic conditions of the Little Ice Age, the continuous presence of indigenous people in mountain areas enabled greater knowledge of natural processes and increased opportunities for coexistence and adaptation. Socio-economic development of Upper Sava Valley in the 20th century caused large changes and transformation from primary to tertiary sector, mostly tourism. As the positioning of traditional settlement is based on social memory it is important to support local indigenous inhabitants and maintain their awareness of local natural processes - to plan new safe settlement areas. The inhabitants need to have direct contact with the natural environment and access to modern hazard and spatial development-related data. For example, the placement of touristic objects in landscape considers alternative and additional criteria to include also the potential danger of natural hazards to the temporary population.

Acknowledgments: The authors acknowledge the financial support from the Slovenian Research Agency research core funding Geography of Slovenia (P6-0101) and Slove- 
nian Research Agency research grant J6-6853 Resilience of the alpine environment from the perspective of natural hazards.

\section{References}

[1] Marchi L., Tecca P. R. Alluvial fans of the Eastern Italian Alps: morphometry and depositional processes. Geodinamica Acta 2015, 8(1), 20-27. https://doi.org/10.1080/09853111.1995. 11105270

[2] Komac B., Social Memory and geographical memory of natural disasters. Acta geographica Slovenica 2009, 49(1)K199-226. https://doi.org/10.3986/AGS49107

[3] Komac B., Natek K., Zorn M., Geografski vidiki poplav v Sloveniji. Geografija Slovenije 20. Ljubljana: Založba ZRC; 2008.

[4] Sodnik J., Mikoš M., Estimation of magnitudes of debris flows in selected torrential watersheds in Slovenia. Acta geographica Slovenica 2006, 46(1), 93-123. https://doi.org/10.3986/ AGS46104

[5] Arattano M., Conte,R., Franzi,L., Giordan,D., Lazzari,A., Luino, F., Risk management on an alluvial fan: a case study of the 2008 debris-flow event at Villar Pellice (Piedmont, N-W Italy). Natural Hazards and Earth System Sciences 2010, 10(5), 999-1008. https://doi.org/10.5194/nhess-10-999-2010

[6] Nared J., Razpotnik Visković N., Cremer-Schulte D., Brozzi R., Cortines Garcia F., Achieving sustainable spatial development in the Alps through participatory planning. Acta geographica Slovenica 2015, 55(2), 363-373. doi: 10.3986/AGS.1631.

[7] Nared J., Visković Razpotnik N., Komac B., The Alps: A physical geography, political, and program framework. Acta geographica Slovenica 2015, 55(1), 165-172. https://doi.org/10.3986/AGS. 1970

[8] Schraml K., Oismüller M., Stoffel M., Hübl J., Kaitna R., Debris-flow activity in five adjacent gullies in a limestone mountain range. Geochronometria 2015, 42, 60-66. https://doi.org/10.1515/geochr-2015-0007

[9] Brunetti Brunetti M.T., Peruccacci S., Rossi M., Luciani S., Valigi D., Guzzetti F., Rainfall thresholds for the possible occurrence of landslides in Italy. Natural Hazards and Earth System Sciences 2010, 10, 447-458, https://doi.org/10.5194/nhess-10447-2010.

[10] Mazzorana B., Scherer C., Marangoni C. Additional torrent control strategies on debris flow alluvial fans with extremely high vulnerable settlements. In: 4th International Congress on Environmental Modelling and Software; 2008; Barcelona, Catalonia, Spain; 2008. p 1492-1499.

[11] Chernomorets Savernyuk E., Debris flow hazards for mountain regions of Russia: regional features and key events. Natural Hazards 2017, 88, 1-16. https://doi.org/10.1007/s11069-0172841-3

[12] Mayer B., Stoffel M., Bollschweiler M., Hübl J., Rudolf-Miklau F., Frequency and spread of debris floods on fans: A dendrogeomorphic case study from a dolomite catchment in the Austrian Alps. Geomorphology 2010, 118, 199-206.

[13] Crosta G. B., Frattini P., Controls on modern alluvial fan processes In the Central Alps, Northern Italy. Earth Surf. Process.
Landforms 2004, 29, 267-293.

[14] Zorn M., Komac B., Geomorfologija in prostorsko planiranje. Urbani Izziv 2006, 17(1/2), 66-72.

[15] Komac B., Zorn M., Vloga zavarovanih območij pri blažitvi naravnih nesreč. In: Nared J., Perko D., Razpotnik Visković N. Razvoj zavarovanih območij v Sloveniji. Regionalni razvoj 3. Ljubljana: Založba ZRC; 2011, p. 113-126.

[16] Zorn M., Komac B., Damage caused by natural disasters in Slovenia and globally between 1995 and 2010. Acta geographica Slovenica 2011, 51(1), 7-41. https://doi.org/10.3986/AGS51101

[17] Zorn M., Komac B., Ciglič R., Prilagajanje naravnim nevarnostim z urejanjem prostora - primer poplav in zemeljskih plazov v Občini Idrija. In: Nared J., Polajnar Horvat K., Razpotnik Visković N. Prostor, regija, razvoj. Regionalni razvoj 6. Ljubljana: Založba ZRC; 2017, p. 39-51.

[18] Petek F., Urbanc, M., The Franziscean Land Cadastre as a Key to Understanding the 19th-century Cultural Landscape in Slovenia. Acta geographica Slovenica 2004, 44(1), 89-113.

[19] Grčić M., Grčić L., Sibinović M., The geographical position of the town of Rasa based on Porphyrogenitus and medieval maps. Acta geographica Slovenica 2018, 58(1), 39-51. https://doi.org/ 10.3986/AGS.1949

[20] Marchi L., Cavalli M, D’Agostino V., Hydrogeomorphic processes and torrent control works on a large alluvial fan in the eastern Italian Alps. Nat. Hazards Earth Syst. Sci. 2010, 10, 547-558.

[21] Lepeška T., Dynamics of development and variability of surface degradation in the subalpine and alpine zones (an example from the Velká Fatra Mts.,Slovakia). Opengeosciences. 2016, 8, 771-786.

[22] Guzzetti F., Cardinali M., Reichenbach, P., The AVI Project: A bibliographical and archive inventory of landslides and floods in Italy. Environmental Management 1994, 18(4), 623-633.

[23] Barnikel F., The value of historical documents for hazard zone mapping, Nat. Hazards Earth Syst. Sci. 2004, 4, 599-613.

[24] Marchi L., Cavalli M., Procedures for the Documentation of Historical Debris Flows: Application to the Chieppena Torrent (Italian Alps). Environmental Management 2007, 40(3), 493-503.

[25] Helsen M. M., Koop P. J. M., Van Steijn H., Magnitudefrequency relationship for debris flows on the fan of the Chalance torrent, Valgaudemar (French Alps), Earth Surf. Proc. Land. 2002, 12, 1299-1307.

[26] Stoffel M., Magnitude-frequency relationships of debris flows A case study based on field surveys and tree-ring records. Geomorphology 2010, 116(1-2), 67-76.

[27] Zorn M., Komac B., Naravne nesreče in družbena neodgovornost. Geografski vestnik, 2015, 87(2), 75-93. https://doi.org/10.3986/GV87205

[28] Jesenovec S., Pogubna razigranost: 110 let organiziranega hudourničarstva na Slovenskem: 1884- 1994. Ljubljana: PUH Podjetje za urejanje hudournikov, 1995.

[29] Gams I., Prispevek k mladokvartarni geomorfologiji v Zgornjesavski dolini. Geografski zbornik 1992, 32, 63-75.

[30] Mikoš M., Sediment budget of the Sava River from Jesenice to Mokrice. Gradbeni vestnik 2000, 49, 208-219.

[31] Hrvatin M., Zorn M., Trendi pretokov rek v slovenskih Alpah med letoma 1961 in 2010. Geografski vestnik 2017, 89(2), 9-35. https://doi.org/10.3986/GV89201

[32] Mikoš M., Ocena ogroženosti zaradi delovanja drobirskih tokov. Ljubljana: Faculty of civil engenering and geodesy Ljubljana, 
2006. Endreport.

[33] Zorn M., Komac B., Gabrovec M., Influence of land use changes on erosion in Slovenian Alps. In Kabrda J., Bičík I. Man in the landscape across frontiers : landscape and land use change in Central European border regions. Prague: Charles University, Faculty of Science, Department of Social Geography and Regional Development, 2008.

[34] Zorn M., Komac B., Response of soil erosion to land use change with particular reference to the last 200 years (Julian Alps, Western Slovenia). Revista de geomorfologie 2009, 11, 39-47.

[35] Triglav Čekada M., Aerial laser scanning and real estate databases. Geographical Bulletin 2010, 54(2), 181-194.

[36] Boudou M., Danière B., Lang M., Assessing changes in urban flood vulnerability through mapping land use from historical information. Hydrology and Earth System Sciences 2016, 20, 161173. https://doi.org/10.5194/hess-20-161-2016

[37] Pérez Álvarez J. A., Mayoral Herrera V., Martínez del Pozo J. Á., de Tena M. T., Multi-temporal archaeological analyses of alluvial landscapes using the photogrammetric restitution of historical fiights: a case study of Medellin (Badajoz, Spain). Journal of Archaeological Science 2013, 40(1), 349-364. https://doi.org/10.1016/j.jas.2012.08.025

[38] Ravbar, M., Letališča na soški fronti. Prispevki za novejšo zgodovino 2012, 2, 231-256.

[39] Breg Valjavec M., Ribeiro D. Uporabnost zgodovinskih aeroposnetkov pri preučevanju pokrajinskih sprememb na ozemlju Slovenije. In: Ciglič R., Perko D., Zorn M., Digitalni proctor. GIS v Sloveniji 13. Ljubljana: Založba ZRC, 2016, p. 71-84.
[40] Bohinec V., Postglacialno Korénško jezero. Geografski vestnik 1935, 11, 98-106.

[41] Jež J., Mikoš M., Trajanova M., Kumelj Š., Budkovič T., Bavec M., Vršaj Koroška Bela - Rezultat katastrofičnih pobočnih dogodkov. Geologija 2008, 51(2), 219-227. https://doi.org/10.5474/geologija.2008.022

[42] Kunaver J., H geomorfologiji dolomitnega prevala Vršič v Julijskih Alpah. Geografski vestnik 1990, 62, 79-98.

[43] Komac B., Zorn M., Pobočni procesi in človek. In: Perko D., Geografija Slovenije 15. Ljubljana: Založba ZRC, 2007.

[44] Palmieri R., Rosenwirth R., Sima F., Val - l'onda - die Flut. 2004. Trieste.

[45] Polajnar J., Visoke vode v Sloveniji leta 2003. Ujma 2004, 17-18.

[46] Polajnar J., Visoke vode rek in poplave. Hidrološki letopis Slovenije 2003. Ljubljana: Agencija RS za okolje, 2006.

[47] Tropeano D., Turconi L., Sanna S., Debris flows triggered by the 29 August 2003 cloudburst in

[48] Val Canale, eastern Italian Alps. In: Mikos M., : Veränderungen im Natur-und Kulturhaushalt und ihre Auswirkungen 1. Klagenfurt: International Research Society Interpraevent, 2004.

[49] Zorn M., Natek K., Komac B., Mass movements and flash-floods in Slovene Alps and surrounding mountains. Studia Geomorphologica Carpatho-Balcanica 2006, 40, 127-145. 